\title{
A Rejoinder to Professor Anand
}

\section{Timothy CAULFIELD*}

In the previous article, Professor Anand provides a detailed analysis of my brief 2001 comment on the Proposal for Legislation Governing Assisted Reproduction.' Much, if not all, of his critique is based on what he believes to be an "ambiguous thesis" and confusion regarding the nature of criminal law. Specifically, he feels I am not clear about what kind of criminal prohibitions I am against.

Since 1996, when Bill C-47 was introduced, ${ }^{2}$ a central issue has been whether statutory prohibitions are flexible and responsive enough to accommodate the area of reproductive genetics. For me, this has been one of the main problems with the Government's approach to the regulation of reproductive genetics. This is a debate which has occurred not only in Canada but in every jurisdiction struggling to craft laws to address this complex area. It was my intent that my 2001 comment would be read in the context of this broader, decade-old debate. Perhaps this was a mistake. So, for the record, let me concisely state my view, a view that I first formulated in 1996 and which has remained consistent: statutory prohibitions are not an appropriate way to regulate the area of reproductive genetics. My experience is that this is a relatively well-known debate and hardly a unique stance. ${ }^{3}$

It is unfortunate that Professor Anand found what is essentially a semantic issue so distracting, as many of his criticisms, though interesting, have little do to with the

Canada Research Chair in Health Law and Policy, Associate Professor, Faculty of Law and Faculty of Medicine and Dentistry, Research Directory, Health Law Institute, University of Alberta.

S. Anand, "Clones, Controversy, Confusion, and Criminal Law: A Reply to Professor Caulfield" (2002) 40 Alta. L. Rev. 493. See Proposal for Legislation Governing Assisted Human Reproduction: Draft Legislation (Health Canada, May 2001), online: Health Canada <www.hcsc.gc.ca/english/ reproduction/legislation.pdf>. It is important to note that the debate has moved forward considerably since the Proposal was introduced in May of 2001 and since my article was published last year. For a review of major developments see T. Caulfield, "Politics, Prohibitions and the Lost Public Perspective: A Comment on Bill C-56: The Assisted Human Reproduction Acr" (2002) 40 Alta. L. Rev. 451 at 451, n. 4 [hereinafter "Politics, Prohibitions"]. The article Professor Anand critiques is T. Caulfield, "Clones, Controversy and Criminal Law: A Comment on the Proposal for Legislation Governing Assisted Human Reproduction" (2001) 39 Alta. L. Rev. 335 [hereinafter "Clones, Controversy"].

: Bill C-47, An Act respecting human reproduction technologies and commercial transactions relating to human reproduction, 2d Sess., 35th Parl., 1996.

'Indeed, as noted in "Politics, Prohibitions," supra note 1 at $462, I$ consider this to be the dominant - though not the only - view in the legal academic literature related to the regulation of reproductive genetics. To cite just one example. the Hastings Center, an American bioethic research institute, just completed a two-year international multi-disciplinary research project on reproductive genetics (I was a working member on the project). One of the major findings was that the United States should adopt a flexible regulatory regime. E. Parens \& L. Knowles, "Reproductive Genetics and Public Policy: Shaping Our Future" [forthcoming]. For examples of my earlier work on this topic see T. Caulfield, M. Hirtle \& S. LeBris, "NRT's: Is Criminalization the Solution for Canada?" (1997) 18 Health L. in Can. 3; and T. Caulfield \& M. Hirtle, "Regulating the Genetic Revolution" (1999) 5 Molecular Medicine Today 198. 
issues at the heart of this debate. ${ }^{4}$ In addition, concern about the stigma of criminal law, sentencing flexibility, and the availability of common-law defences rarely, if ever, appear in the literature on regulating reproductive technologies. That said, Professor Anand has provided food for thought and I welcome the perspective that this criminal law expert provides, and I will briefly comment on two key policy points raised in his reply.

First, as to the issue of social consensus, the main point in my 2001 comment, and one that I reiterate in my comment on the legislation in this issue, is that policy-makers cannot rely on social consensus as a justification for the enactment of statutory prohibitions. ${ }^{6}$ Given available evidence, it seems clear that there is currently no public consensus nor agreement within the academic, religious or even scientific communities about the harms and benefits associated with of many of the relevant technologies. Nor, despite Anand's suggestion to the contrary, is there any demonstrated consensus about the application of core values relevant to this area, such as the role of human dignity. Without social consensus, there is a heightened need for the government to support the regulatory approach based on strong, foundational, policy rationales - which are, for many of the prohibitions, also still absent.

Among the more challenging areas of inquiry - for policy-makers and policy researchers alike - is to determine what constitutes social consensus and how it ought to be used. At some level, however, public opinion must surely be relevant. ${ }^{7}$ As noted in the Canadian Government's The Criminal Law in Canadian Society, the criminal law should be an instrument of "last resort" and should only be used to respond to

- It would appear that much of Anand's discomfort with my piece flows from my frequent use of the term "criminal prohibitions." When I use the term I am referring to the proposed legislation's statutory list. I explicitly describe and reference the statutory list in the introduction to the comment (supra note 1 at $336, n$. 6) and, on page 338, refer to the difficulty associated with "[a]mending the current list of prohibitions." I assumed the reader would understand this and felt it unnecessary to specifically refer to the statutory list when I used the term "criminal prohibition," as I do in the conclusion. However, Anand's criticism highlights the importance of using precise language in this context. As such, henceforth I will use the term "statutory prohibitions." Not surprisingly, I take issue with many, if not all of Anand's criticisms of my sources and analysis. However, given the limited space available for this rejoinder, it seemed more constructive to focus on a few substantive policy concerns.

"Politics, Prohibitions," supra note 1. Indeed, much of my 2001 comment is devoted to this argument but is not referenced in Anand's reply. Moreover, I do not, as suggested, cite Harvison Young and Wasunna as authority for the role of social consensus. Rather, I merely note that the "[l]ack of consensus was noted by [Harvison Young and Wasunna]." See "Clones, Controversy," supra note 1 at 338, n. 19.

7 The federal government certainly thinks so, given the amount of time and resources it has expended on public consultation. Indeed, many of the surveys I reference in "Politics, Prohibitions" were commissioned by the government. See supra note 1 at $\mathrm{nn} .20$ and 21 .

* Canada, The Criminal Law in Canadian Socieny (Ottawa: Law Reform Commission of Canada, 1982) at 44. 
"conduct which is culpable, seriously harmful, and generally conceived of as deserving of punishment." The word "consensus" is not used, but the point is clear.

Second, there is the issue of flexibility. A number of commentators have recently suggested that statutory prohibitions are, in fact, flexible enough to handle this dynamic area, noting that Parliament technically can enact and amend laws relatively quickly. ${ }^{10}$ But, in reality, Parliament rarely moves quickly on such matters. We have been trying to enact legislation in this area for almost ten years. There is little reason to believe that Parliament will be inclined to move more quickly in the future. More important, however, once the laws are enacted, they will be difficult to alter in response to new scientific developments or new social concerns. As noted in The Criminal Law in Canadian Society:

The practice of a century in Canada has shown that Parliament can, and has, found it relatively easy to subject conduct to criminal sanctions, in response to specific problems or particular demands. But once an act has been made criminal, it is difficult to remove or lessen criminal penalties, even in response to changes in public attitudes. perceived inconsistencies in application. or emerging experience demonstrating that use of the criminal law might be excessive."

It should not be forgotten that the need for flexibility and responsiveness is one of the accepted justifications for the very existence of regulatory schemes generally. As noted by Jones and de Villars:

There are a variety of reasons for subordinate legislation. including:... c) The power to delegate to an administrator allows greater flexibility in applying statutory provisions to changing circumstances. d) The need for rapid governmental action may require faster administrative response than can be achieved by amending parent legislation. [And] e) Innovation and experimentation in solving social problems may not be possible if parent legislation must be amended. ${ }^{12}$

In the end, and perhaps surprisingly, it appears that Anand and I largely agree. We agree that, as a matter of constitutional law, the government can use the criminal law power to regulate this area; that a regulatory approach "may be the answer"; ${ }^{13}$ that the use of a negative resolution is one way to enhance the democratic accountability of the regulatory body; and that Bill C-56 may only require minor revisions. A close reading of both our papers also reveals a degree of agreement concerning the complex role of social consensus. However, for me, how the government constitutionally justifies the

Ibid. at 4 [emphasis added]. This is one of the documents I was said to have inappropriately referenced in relation to the role of social consensus. See Anand, supra note $I$ at 496 . There are, of course, criminal sanctions for not adhering to rules established by the regulatory body in the scheme I advocate, but the regulatory approach allows this inevilable lack of consensus to be addressed in a more subtle fashion through. for example. an ongoing and dynamic consultation process. See "Politics, Prohibitions and the Lost Public Perspective," supra note 1. See F. Baylis \& J. Downie, "Ban Cloning: Do you copy?" Globe \& Mail (2 July 2002) A13. Supra note 8 at 46.

D. Jones \& A. de Villars, Principles of Administrative Law, 2d Edition (Scarborough: Carswell, 1994) at 83.

Anand, supra note 1 at 504-505. 
law and how criminal law would be applied are far less interesting than ensuring that the scheme has the characteristics necessary to effectively and responsibly regulate this increasingly dynamic area. 